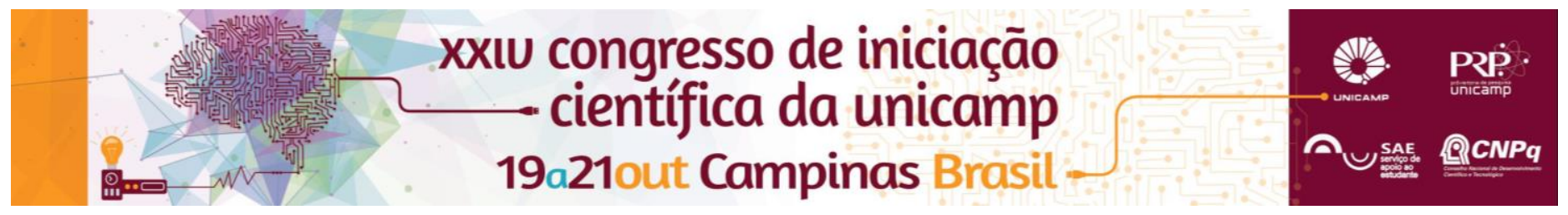

\title{
Occurrence of Environmental Crimes in the São Paulo North Coast
}

\author{
Sônia Regina da Cal Seixas (PQ), Gabriel Luis de Oliveira (IC)*
}

\begin{abstract}
The presented study is inserted on two projects in progress "Mental health, violence and urban global environmental change in the Export Corridor Tamoios - D. Pedro I, São Paulo, Brazil" (FAPESP n. 2012/17173-5), and "Urban Coastal Transformations: Promoting transnational policy development in the governance of environmental quality and crime reduction" (Newton Fund/CONFAP/Research Council UK) both coordinated by the guiding professor. Looking for analyze the cumulative effects on the urban and environmental systems about the occurrence of environmental crimes, employing the reference frame of "urban global environmental changes" in urban communities of Caraguatatuba and Atibaia.
\end{abstract}

\section{Key words:}

environmental crimes, GEC, São Paulo North Coast

\section{Introduction}

The occupancy of coastal urban space, both in Brasil as in the UK introduce conflicts due territory occupation and the dynamics of economic and social structures that policy makers breast. Therefore, the concern about the environmental quality and crime reduction are present. These conflicts are outcome of expressive changes on economic activities from those areas, both related to industry growth and the tourism spaces demand. Such changes are nurtured the population growth through São Paulo coast and the migration for those coastwise cities have a negative impact both on environmental quality and crime.

\section{Results and Discussion}

Inserted in a referential frame of "urban global environmental changes" the present study looks for analyze the cumulative effects of those changes on urban system about the occurrence of environmental crimes in urban communities of Caraguatatuba and Atibaia, discuss the institutional intervention degree and the local communities acclimations. Therefore, the more recurrent environmental crimes data were collect, systematize and analyze. Looking for categorize it on $1997-2014$ period. The occurrence of environmental crimes was also georeferenced.

\section{Conclusions}

The data were collect through search at São Paulo Environmental State Secretary Data Bank, at Environmental Police Regional Offices Data Bank, at CETESB Regional Offices Data Bank and in the files of public ministry, at Atibaia and Caraguatatuba Forums. The environmental crimes data recurrent for the period of study related to the cities present have allowed us to make a widest mapping in the region, also dialoguing with others researchers from the area and from the UK.

\section{Acknowledgement}

Thanks to FAPESP (process n. 2013/17173-5) and to Newton Fund/CONFAP/Research Council UK for the support on cited research projects. Thanks to CNPq for the Research Productivity Scholarship of the first author, and to PIBIC/UNICAMP-IC for the scholarship of the second author.

BOTTERILL, D. (2014). Constructionism - A Critical Realist Response, Annals of Tourism Research, 48, 292-298.

BOTTERILL, D.; JONES, T. (Eds.) (2010). Tourism and Crime: Key Themes. Oxford: Goodfellow

BOTTERILL, D; SEIXAS, S.C.; HOEFEL, J.L. (2013). Tourism and Transgression: Resort Development, Crime and the Drug Economy, Tourism Planning and Development, 11, 1, 27-41.

BOTTERILL, D.; POINTING, S.; HAYES-JONKERS, C.; JONES, T.; RODRIGUEZ, C.; A.CLOUGH (2013). Violence, tourism, security and critical realism, Annals of Tourism Research, 42, 311-333.

BOTTERILL, D; SEIXAS, S.R.C (PIs). Urban Coastal Transformations: Promoting transnational policy development in the governance of environmental quality and crime reduction. Research Project, Newton Fund/CONFAP/Research Council UK, 2015

SEIXAS, S.R. C; HOEFFEL, J.L.; BOTTERILL, D.; VIANNA, P.V.C.; RENK, M. (2014). 'Violence, tourism, crime and the subjective: Opening new lines of research', in H.Andrews (ed) Tourism and Violence, Farnham, UK Ashgate, p.145 - 163.

SEIXAS, S.R.C; HOEFFEL, J.L.; ROCHA, J.V.; NUNES, R. J; BOTTERILL, D. Saúde mental, violência e mudanças ambientais globais urbanas no corredor de exportação Tamoios - D Pedro I, São Paulo, Brasil. Projeto de Pesquisa; FAPESP n. 2013/17173-5), 2014.

SELBY, M.; SELBY, H.; BOTTERILL, D. (2010) Tourism, image and fear of crime. In: D. Botterill and T. Jones (Eds.) Tourism and Crime: Key themes, Oxford: Goodfellow Publishers, p. 187-214. 